\title{
SULPHUR UTILIZATION BY YEAST
}

\author{
G. A. MAW \\ Arthur Guinness, Son $\mathcal{E}$ Co. Ltd., Dublin, Ireland
}

\section{INTRODUCTION}

'This communication is restricted to a consideration of Saccharomyces yeasts, and deals with the requirements for sulphur and with the uptake, turnover and distribution of sulphur in these organisms.

Of the sulphur compounds which occur in yeast, quantitatively the most important are the amino-acids cysteine, cystine and methionine. Cystine and methionine are located almost entirely in the proteins, and the glutathione o: the cytoplasm accounts for the bulk of the cysteine. Other sulphurcontaining constituents of importance are present, including derivatives of biotin and thiamine, traces of sulphate in inorganic and ester form, as well as in nucleotide combination as "active sulphate", derivatives of cysteine such as cysteamine, a part of the coenzyme A molecule, and derivatives of methionine such as $S$-adenosylmethionine. However, these compounds collectively represent only a small fraction of the total sulphur of the cell.

\section{SULPHUR GONTENT OF YEASTS}

A survey of the available literature on the total sulphur content of brewer's and baker's yeasts (see Table 1) reveals a fairly wide range of values. Much of the variation undoubtedly arises from the variety of analytical procedures used and from the fact that many of the analyses were carried out on commercial preparations of dried yeasts grown on industrial or vegetable wastes, and for which the exact conditions of culture, harvesting, separation from residual medium, etc., were not specified. From the standpoint of sulphur utilization the nutritional history of a yeast culture is important since the

Table 1. Total sulphur content of Saccharomyces cerevisiae

\begin{tabular}{|c|c|c|}
\hline Authors & Yeast strains & $\begin{array}{l}\text { Total sulphur } \\
\text { (\% of dry wt. } \\
\text { of yeast) }\end{array}$ \\
\hline $\begin{array}{l}\text { Fink and Just }{ }^{1} \\
\text { Block and Bolling }{ }^{2} \\
\text { Ilent }^{3} \\
\text { C'yörgy }^{4} \\
\text { McManus, Schultz and Maynard } \\
\text { Lindan and Work } \\
\text { Suomalainen and Keränen }\end{array}$ & $\begin{array}{l}\text { Brewer's strain } \\
2 \text { Baker's strains } \\
5 \text { Brewer's strains } \\
\text { Baker's strain } \\
\text { Brewer's strain } \\
\text { Baker's strain } \\
4 \text { Baker's strains } \\
\text { Baker's strain } \\
\text { Brewer's strain } \\
3 \text { Baker's strains } \\
\text { Brewer's strain }\end{array}$ & $\begin{array}{c}0 \cdot 19,0 \cdot 20 \\
0.34-0.44 \\
\\
0 \cdot 53 \\
0 \cdot 65 \\
0 \cdot 86 \\
0 \cdot 35-0.45 \\
0 \cdot 36 \\
0 \cdot 55 \\
0 \cdot 28-0 \cdot 34 \\
0 \cdot 44-0.49\end{array}$ \\
\hline
\end{tabular}




\section{G. A. MAW}

sulphur content, and more particularly the methionine and glutathione contents, can vary with the nature and amount of assimilable sulphur in the growth medium ${ }^{8-10}$. According to some authors ${ }^{7}$ aeration is a further factor and can lead to lower total sulphur values. Significant differences between the sulphur content of brewer's and baker's yeasts have been reported $^{6,7}$, although this is not a general finding ${ }^{2}$. On the basis of the more reliable data an average value for the sulphur content of these yeasts appears to be about 0.4 per cent of the dry weight.

Reported values for cystine, methionine and glutathione in yeasts are equally varied. Thorne ${ }^{11}$ quotes the following range of figures (expressed as a percentage of the dry weight): glutathione-S, $0.05-0.10$; cystine-S, $0 \cdot 13-0 \cdot 27$; methionine-S, $0 \cdot 15-0 \cdot 28$. Glutathione-S appears to represent some 20-30 per cent of the total sulphur, about 90 per cent being present as reduced glutathione 12,13 . In a sulphur-deficient medium the glutathione content can be reduced to as little as one-tenth of normal values ${ }^{10}$.

Some data for cystine and methionine are given in Table 2. The methionine content can be increased considerably (up to three-fold) by inclusion

Table 2. Cystine and methionine content of Saccharomyces cerevisiae (expressed as $\mathrm{g} \mathrm{S} / 100 \mathrm{~g}$ dry wt. yeast)

\begin{tabular}{|c|c|c|c|}
\hline Authors & Yeast strains & Cystine-S & Methionine-S \\
\hline $\begin{array}{l}\text { Stokes } \text { et al. }{ }^{14} \\
\text { Stokes and Gunness } \\
\text { Block and Bolling }^{2} \\
\text { Horn, Jones and Blum } \\
\text { Barton-Wright }^{\mathbf{9}} \\
\text { Brunner }^{17} \\
\text { Lindan and Work }^{6} \\
\text { Tamura } \text { et al. }{ }^{18} \\
\text { Chiao and Peterson } \\
\text { Baumgarten, Mather and Stone } \\
\text { Nelson et al. }{ }^{21}\end{array}$ & $\begin{array}{l}\text { Brewer's strain } \\
1 \text { Strain } \\
2 \text { Baker's strains } \\
5 \text { Brewer's strains } \\
\text { Brewer's strain } \\
\text { Brewer's strain } \\
6 \text { Brewer's strains } \\
\text { Baker's strain } \\
\text { Brewer's strain } \\
\text { Brewer's strain } \\
6 \text { Strains } \\
\text { Yeast preparations } \\
\text { 53 Strains }\end{array}$ & $\begin{array}{l}\bar{Z} \\
0 \cdot 11-0 \cdot 13 \\
- \\
\overline{-} \\
0 \cdot 12-0 \cdot 19 \\
0 \cdot 21 \\
0 \cdot 29 \\
\overline{-} 07-0 \cdot 10 \\
-\end{array}$ & $\begin{array}{c}0 \cdot 17,0 \cdot 18 \\
0 \cdot 14 \\
0 \cdot 25-0 \cdot 32 \\
0 \cdot 12 \\
0 \cdot 12-0 \cdot 19 \\
- \\
- \\
0 \cdot 34 \\
0 \cdot 15-0 \cdot 18 \\
0 \cdot 15,0 \cdot 32 \\
0 \cdot 11 \text { (av.) }\end{array}$ \\
\hline
\end{tabular}

of the amino-acid in the growth medium?. Methionine supplementation also leads to a marked increase in the content of $S$-adenosylmethionine ${ }^{22}$. The variations among the published values make it difficult to obtain a reliable estimate of the ratio of cystine-S to methionine-S in yeast, especially as few workers have attempted both analyses on the same yeast sample.

\section{SULPHUR DISTRIBUTION STUDIED WITH THE AID OF SULPHUR-35}

Tracer experiments using sulphur-35 have been carried out with a brewer's strain of Saccharomyces cerevisiae which have provided data on the sulphur content of the yeast and on the relative amounts of cystine and methionine present. Yeasts utilize inorganic sulphate for growth, and in these experiments the growth medium for the brewer's yeast contained 
$\mathrm{Na}_{2}{ }^{35} \mathrm{SO}_{4}(0.78 \mathrm{mM}$, equiv. to $25 \mathrm{mg} \mathrm{S} / 1$. $)$ as the sole sulphur source. Incorpcration of sulphate-S into the yeast was determined from both the percentage loss of sulphur-35 from the medium and the appearance of sulphur-35 in the cells. The course of sulphate incorporation closely paralleled that of yeast growth (Figure 1) and during the phase of active growth, sulphate-S incorporation into whole cells or into the protein fraction was proportional to the amount of cells formed (Figure 2).

Less than 5 per cent of the sulphur-35 taken up was released back into the medium in organic form and since labelled sulphate was the only source

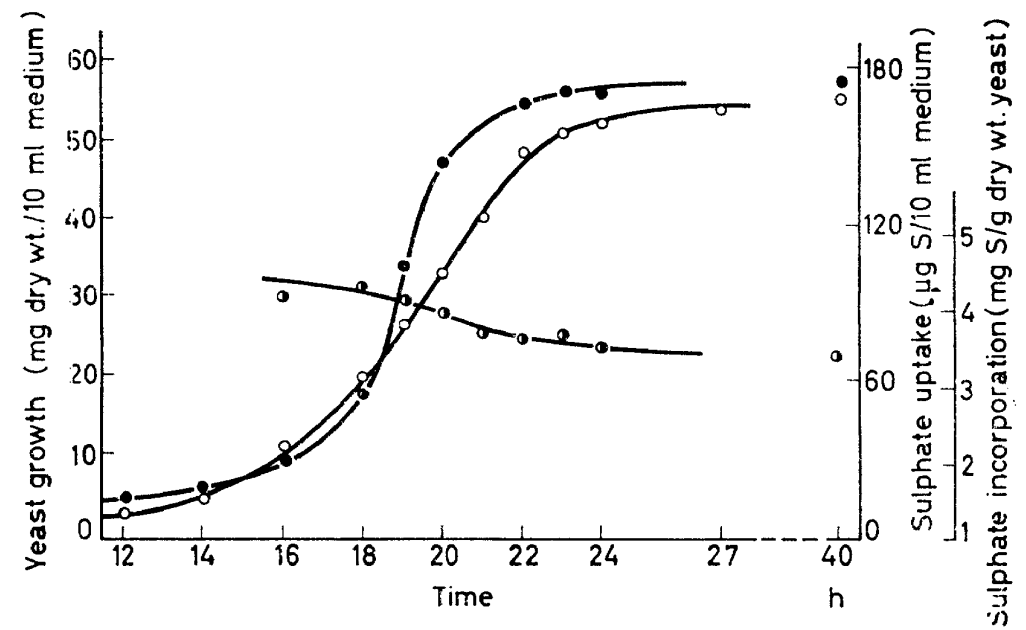

Figrure 1. Growth of yeast and incorporation of $\left[{ }^{35} \mathrm{~S}\right]$-sulphate-sulphur into yeast as a function of time: $\circlearrowleft-0$, yeast growth; poration into yeast; $\mathrm{Na}_{2}{ }^{35} \mathrm{SO}_{4}$ in medium $0.78 \mathrm{mM}$; temperature $30^{\circ}$

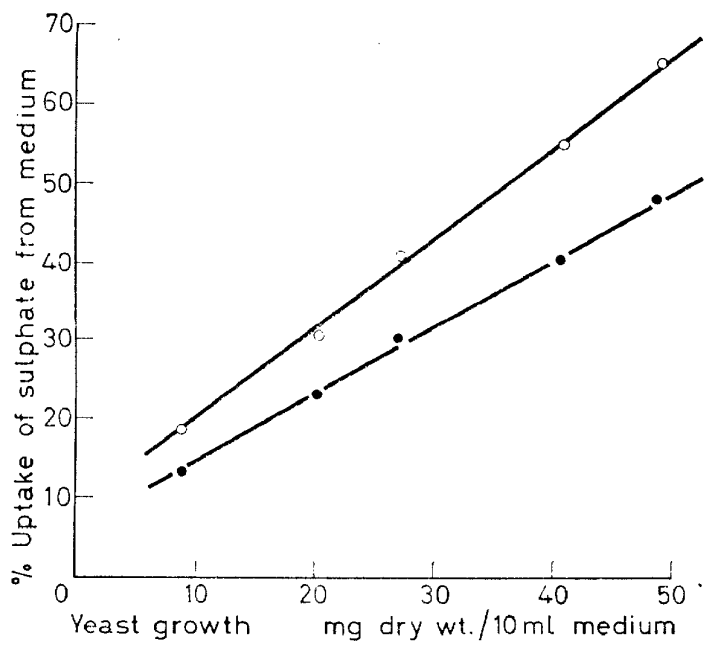

Figure 2. Relation between $\left[{ }^{35} \mathrm{~S}\right]$-sulphate incorporation and yeast growth: $\bigcirc-\bigcirc$, whole cells; - TCA-insoluble fraction; $\mathrm{Na}_{2}{ }^{35} \mathrm{SO}_{4}$ in medium $0.78 \mathrm{mM}$; temperature $30^{\circ}$ 


\section{G. A. MAW}

of sulphur, its loss from the medium provided a reliable measure of the total sulphur content of the yeast. A group of 26 experiments gave a value of $0.35( \pm 0.08) \mathrm{g} \mathrm{S} / 100 \mathrm{~g}$ dry wt. yeast. This value agreed with sulphur determinations made on samples of the yeast after ashing with cupric nitrate ${ }^{23}$, or combustion by the Schöniger flask method, the mean of 24 such determinations being $0.36( \pm 0.03) \mathrm{g} \mathrm{S} / 100 \mathrm{~g}$ dry wt. yeast. Under the conditions chosen and with sulphate as the sulphur source, the sulphur content showed little variation over the growth period (see Figure 1) and was independent of the sulphate concentration of the medium over a wide range (10-100 $\mathrm{mg}$ sulphate-S/1.). The value of 0.35 per cent obtained from these experiments is in accord with the earlier data of Block and Bolling ${ }^{2}$ and of McManus, Schultz and Maynard ${ }^{5}$.

The ratio of cystine to methionine was determined on yeast grown in the presence of $\mathrm{Na}_{2}{ }^{35} \mathrm{SO}_{4}$ as sole sulphur source by a procedure which will be described in detail elsewhere ${ }^{24}$. In outline it was as follows: samples of yeast and also of the trichloroacetic acid-insoluble fraction of yeast, amounting to $6 \mathrm{mg}$ dry wt., were first oxidized with performic acid at $0^{\circ}$, following the method described recently by Schram, Moore and Bigwood ${ }^{25}$ and Moore ${ }^{26}$, the cystine and methionine residues present being converted to cysteic acid and methionine sulphone respectively. The oxidized yeast was then hydrolysed with $6 \mathrm{~N}$ hydrochloric acid. Hydrolysis after rather than before oxidation circumvents losses of sulphur which can occur due to the prolonged action of hydrochloric acid on cystine and methionine ${ }^{5,19}$. The hydrolysate was subjected to one-dimensional chromatography on Whatman 3MM paper using phenol:acetic acid:water $(160: 1: 40)$ as solvent, and the chromatogram then scanned for sulphur-35. Two clearly defined radioactive bands were obtained corresponding to cysteic acid and methionine sulphone, with well separated $R_{f}$ values of 0.10 and 0.40 respectively. The radioactive bands were cut from the chromatogram, combusted separately by the Schöniger flask technique and the labelled sulphate obtained converted to benzidine sulphate which was then assayed with a thin endwindow Geiger-Muller tube as described previously 27 . The ratios of the counts for the cysteic acid and methionine sulphone bands on each chromatogram gave the required cystine/methionine ratio. Close agreement was obtained among successive determinations for this ratio in an extensive series of experiments. The summarized data for three Saccharomyces yeasts is shown in Table 3.

It will be seen that the ratios are virtually the same in the three yeasts. In the protein methionine predominates and, taking cystine and methionine as the major sulphur constituents, a ratio of 0.63 corresponds to a cystine

Table 3. Cystine-methionine ratios of some Saccharomyces yeasts

\begin{tabular}{l|c|c}
\hline \multicolumn{1}{c|}{ Yeast } & \multicolumn{2}{c}{ Cystine-S/Methionine-S } \\
\hline & Whole yeast & Yeast protein \\
\hline S. cerevisiae (Brewer's strain) & $1 \cdot 16( \pm 0 \cdot 05)$ & $0 \cdot 63( \pm 0 \cdot 02)$ \\
S. cerevisiae (Baker's strain) & 1.21 & $0 \cdot 64$ \\
S. carlsbergensis & $1 \cdot 16$ & 0.65 \\
\hline
\end{tabular}




\section{SULPHUR UTILIZATION BY YEAST}

content of 38.7 per cent and a methionine content of $61 \cdot 3$ per cent of the protein-S. In whole cells there is slightly more cystine than methionine, this being accounted for by the appreciable amount of cysteine present as glutathione in the non-protein fraction of the cells. It is of interest that in detailed studies of the distribution of sulphur in Escherichia coli, Roberts et al. ${ }^{28}$ obtained very similar cystine/methionine relationships, namely, equimolar amounts in whole cells and a ratio of $1: 2$ for cystine-S to methionine-S in the protein.

\section{SULPHUR AND YEAST GROWTH}

A sotirce of available sulphur is essential for yeast growth. Almost all species of yeasts are able to utilize inorganic sulphate and methionine as suiphur sources, but considerable differences have been found in their ability to assimilate the sulphur of cysteine, cystine and glutathione ${ }^{29,30}$, as well as that of other organic sulphur compounds. Among Saccharomyces yeasts sulphate has been reported as the best source and methionine as slightly less effective, although in some strains it is equivalent to sulphate ${ }^{29}$. Glutathione utilization is generally equivalent to, or slightly less effective than, that of methionine, although the inability of a baker's yeast to grow on this compound has been reported ${ }^{30}$. Cystine and cysteine are at best poorly ctilized or are ineffective as sulphur sources ${ }^{10,29-31}$.

The response of a brewer's yeast to sulphate and to some sulphurcontaining amino-acids is shown ${ }^{31}$ in Figure 3. Optimum growth was

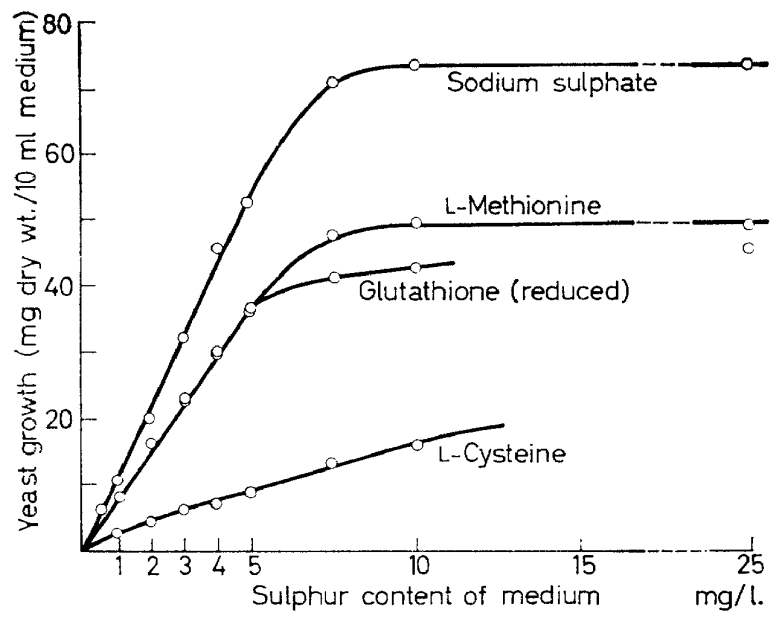

Fizure 3. Growth of a brewer's strain of $S$. cerevisiae on various sulphur sources; growth determined after 2 days at $30^{\circ}$

(Reproduced by courtesy of the Journal of the Institute of Brewing)

obtained with concentrations of sulphate above $10 \mathrm{mg} \mathrm{S} / \mathrm{l}$, the growth response being practically linear up to a level of $6 \mathrm{mg} \mathrm{S} / 1$. The response to methionine and to glutathione showed a similar pattern, but less yeast was produced. However, when added to the sulphate-containing medium both 


\section{G. A. MAW}

compounds increased the rate of growth (Table 4), although the final yeast yield was unaltered. These compounds probably stimulate growth by supplying the intact molecules of methionine and cysteine respectively for protein synthesis, and, as will be descibed below, the role of methionine in this connection is accentuated by its very rapid rate of entry into the yeast ${ }^{27}$.

Table 4. Effects of some sulphur compounds on the growth of a brewer's yeast in a medium containing sulphate

$\mathrm{Na}_{2} \mathrm{SO}_{4}$ and sulphur compounds in medium $0 \cdot 78$ $\mathrm{mM}$ (25 mg S/1.); period of growth $24 \mathrm{~h}$; temperature $30^{\circ}$

\begin{tabular}{l|c}
\hline \multicolumn{1}{c|}{ Compound added } & $\begin{array}{c}\text { Growth of yeast } \\
\text { as a \% of controls }\end{array}$ \\
\hline None & 100 \\
L-Methionine & $132 \cdot 6$ \\
L-Cysteine & $65 \cdot 5$ \\
L-Cystine & $104 \cdot 7$ \\
Glutathione (reduced) & $117 \cdot 9$ \\
S-Methyl-L-cysteine & $\mathbf{8 5 . 2}$ \\
Taurine & $103 \cdot 3$ \\
\hline
\end{tabular}

Cystine was completely ineffective as a sulphur source. At low concentrations cysteine supported limited growth but at concentrations above about $25 \mathrm{mg} \mathrm{S} / 1$. cysteine was toxic and produced diminished growth (Figure 4), no growth occurring in the presence of $200 \mathrm{mg}$ cysteine-S/1.10 Cysteine in low concentrations acted as a supplementary sulphur source in the presence of sub-optimum concentrations of sulphate, methionine or glutathione, but at concentrations above $25 \mathrm{mg} \mathrm{S} / 1$. it depressed growth, and this effect could

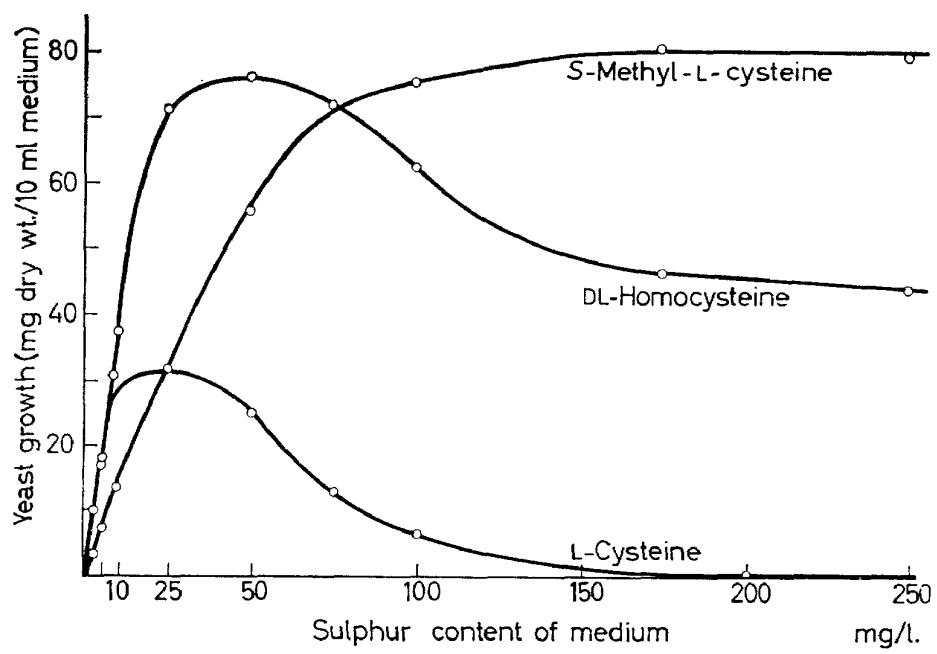

Figure 4. Growth of a brewer's strain of $S$. cerevisiae with various sources of sulphur in the medium; growth determined after 2 days at $30^{\circ}$

(Reproduced by courtesy of the Journal of the Institute of Brewing) 


\section{SULPHUR UTILIZATION BY YEAST}

not be overcome by raising the sulphate level of the medium. Other thiols have been tested for possible growth-inhibitory properties in the presence of sulphate: as shown in Table 5. Mercaptoacetate was as effective as cysteine, homocysteine showed a slight effect, while cysteamine inhibited growth

Table 5. Effects of some thiols on the growth of a brewer's yeast

(Reproduced by courtesy of the Journal of the Institute of Brewing)

Growth measured after 2 days at $30^{\circ}$ and expressed as $\mathrm{mg}$ dry wt. $/ 10 \mathrm{ml}$ medium; sulphate in medium $10 \mathrm{mg} \mathrm{S} / 1$; compounds added at a level of $100 \mathrm{mg} \mathrm{S} / \mathrm{l}$.

\begin{tabular}{|c|c|c|c|}
\hline Compound added & $\begin{array}{l}\text { Growth without } \\
\text { compound }\end{array}$ & $\begin{array}{l}\text { Growth with } \\
\text { compound }\end{array}$ & $\begin{array}{l}\text { \% Inhibition } \\
\text { of growth }\end{array}$ \\
\hline $\begin{array}{l}\text { L-Cysteine } \\
\text { Cysteamine } \\
\text { Glutathione (reduced) } \\
\text { Dl-Homocysteine } \\
\text { DL-Penicillamine } \\
\text { Sodium mercaptoacetate } \\
\text { Sodium mercaptosuccinate }\end{array}$ & $\begin{array}{l}83 \cdot 9 \\
87 \cdot 0 \\
90 \cdot 4 \\
91 \cdot 2 \\
82 \cdot 0 \\
90 \cdot 4 \\
90 \cdot 4\end{array}$ & $\begin{array}{l}35 \cdot 9 \\
82 \cdot 6 \\
86 \cdot 1 \\
80 \cdot 8 \\
80 \cdot 8 \\
39 \cdot 6 \\
86 \cdot 4\end{array}$ & $\begin{array}{r}57 \\
5 \\
5 \\
11 \\
2 \\
56 \\
4\end{array}$ \\
\hline
\end{tabular}

only when the concentration of sulphate was low. Glutathione, mercaptosuccinate and penicillamine were without effect, and the first two compounds, like homocysteine, enhanced growth at sub-optimum sulphate concentrations. Recently $\beta$-mercaptoethanol has also been reported as a growth inhibitor for yeast ${ }^{32}$. Cysteine affects yeast growth by prolonging the lag phase and slowing down the rate of cell division. It is also an effective inhibitor of respiration 10,33 .

A number of amino-acids in equimolar concentration were found to annul the growth inhibition. These included glutamic and aspartic acids, serine, homoserine and $S$-methylcysteine. Glucose-1-phosphate, glucose-6-phosphate, fructose-1,6-diphosphate and zinc salts were among other compounds which produced the same effect. These compounds were unable to reverse the prolongation of the lag phase, but they promoted faster growth in the logarithrnic phase.

Cysteine is known to depress the growth of other micro-organisms $28,34-36$. Its precise mode of action is not clear. It has long been known to be an inhibitor of yeast aldolase ${ }^{37}$ and it may act by complexing with metal ions essential for the activity of respiratory and other enzymes.

\section{SULPHUR TRANSPORT IN YEAST}

The differences in effectiveness of various sulphur compounds as sulphur sources for yeasts may be due to the presence or absence in the cells of enzymes capable of metabolizing these compounds, to the production of toxic effects by certain of these compounds, as appears the case for cysteine, or simply to differences in the ease with which they penetrate the cell membrane. This last factor prompted a study of the transport of sulphur compounds in yeasts. The uptake of inorganic sulphate and of six sulphur amino-acids has so far been studied with the brewer's yeast used in earlier experiments 27,38 . The yeast suspension (final concentration 2 per cent wet wt. pressed yeast/vol.) was added to a medium containing each sulphur 


\section{G. A. MAW}

compound labelled with sulphur-35 and present at a level of $10 \mathrm{mg} \mathrm{S} / \mathrm{l}$. The loss of labelled sulphur from the medium and its corresponding appearance in the yeast were determined at intervals over a 4 -hour period. Figures 5 and 6 show the typical patterns of uptake obtained. They fall into four distinct groups.

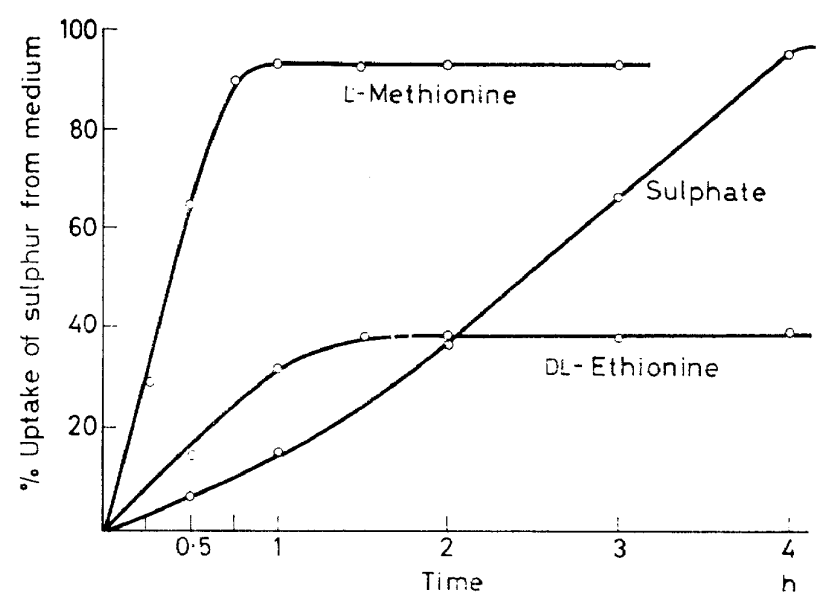

Figure 5. Uptake of sulphur compounds by a brewer's yeast as a function of time; compounds in medium $0.312 \mathrm{mM}$; yeast $2 \%$ (wet wt. pressed yeast/vol.); temperature $30^{\circ}$

(Reproduced by courtesy of the Journal of General Microbiology)

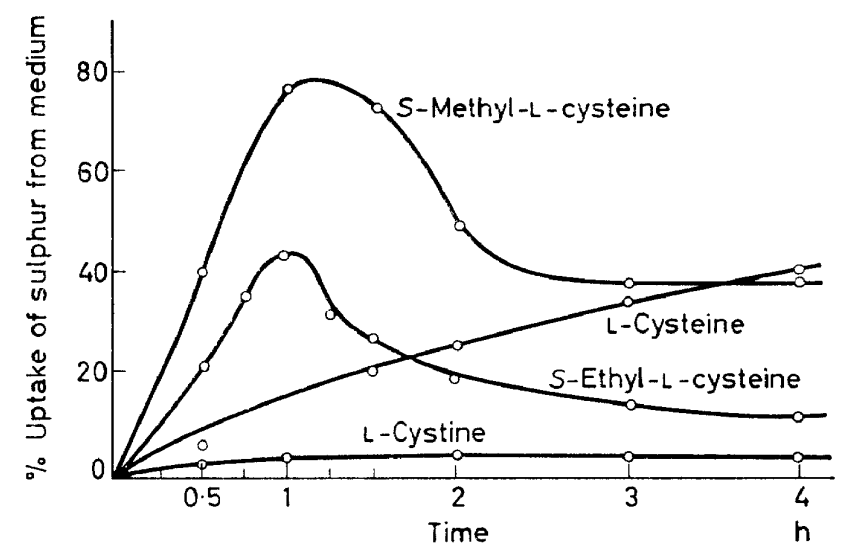

Figure 6. Uptake of sulphur compounds by a brewer's yeast as a function of time; compounds in medium $0.312 \mathrm{mM}$; yeast $2 \%$ (wet wt. pressed yeast/vol.); temperature $30^{\circ}$

(Reproduced by courtesy of the Journal of General Microbiology)

(i) Sulphate and methionine uptake were similar in that they increased steadily with time, resulting in virtually complete removal of each compound from the medium. Methionine uptake was more rapid than that of sulphate and also of all the other sulphur compounds under study.

(ii) Cystine was not taken up by the yeast to any significant extent, and 


\section{SULPHUR UTILIZATION BY YEAST}

cysteine was accumulated at only a very slow rate. This explains in part their ineffectiveness as sulphur sources.

(iii) Ethionine uptake took place to a limited extent, the labelled sulphur then being retained in the yeast and incorporated partially into protein.

(iv) $S$-Methylcysteine and $S$-ethylcysteine were also taken up only to a limited extent, but unlike ethionine part of their sulphur was released back intc the medium ( 75 per cent in the case of $S$-ethylcysteine and 48 per cent in the case of $S$-methylcysteine). The nature of the released sulphur has not so far been established, but chromatographic studies on the medium from $S$-ethylcysteine uptake experiments indicate that at least one compound distinct from the original amino-acid is present.

Sulphate uptake was not greatly increased over a 20 -fold concentration range and methionine uptake was approximately doubled. The transport mechanisms for these two compounds appear to be largely saturated at low concentrations. This is in contrast to the findings with cysteine, $S$-ethylcysteine and ethionine, the uptakes of which were greatly increased by raising their concentration in the medium. Calculations have been made of the ability of the yeast to concentrate sulphate and sulphur amino-acids, the comparative data being shown in Table 6 . Methionine was the most

Table 6. Ability of a brewer's yeast to concentrate sulphur compounds

(Reproduced by courtesy of the Journal of General Microbiology)

[ $\left.{ }^{35} \mathrm{~S}\right]-S u l p h u r$ amino-acids and $\mathrm{Na}_{2}{ }^{35} \mathrm{SO}_{4} 0.312 \mathrm{mM}$; yeast $2 \%$ (wet wt. pressed yeast/vol.); temperature 30 ; uptake period $0.5 \mathrm{~h}$

\begin{tabular}{l|c}
\multicolumn{1}{c|}{ Compound } & $\begin{array}{c}\text { Ratio of internal concentration } \\
\text { of }{ }^{35} \mathrm{~S} \text { in yeast to concentration } \\
\text { in medium }\end{array}$ \\
\hline L-Methionine & $56 \cdot 2$ \\
DL-Ethionine & $11 \cdot 5$ \\
L-Cysteine & $17 \cdot 2$ \\
S-Methyl-L-cysteine & $30 \cdot 5$ \\
-Ethyl-L-cysteine & $21 \cdot 1$ \\
$\mathrm{Na}_{2} \mathrm{SO}_{4}$ & $4 \cdot 9$ \\
\hline
\end{tabular}

readily accumulated compound, being taken up 11 times as rapidly as sulphate and over 3 times as rapidly as cysteine. Further experiments have shown that after $1 \mathrm{~h}$ the yeast was able to accumulate $0.46 \mathrm{mg}$ sulphate-S/g dry wt. yeast. Of this 59.7 per cent became associated with the protein fraction, $5 \cdot 1$ per cent was present as free sulphate and $35 \cdot 2$ per cent was present as other forms of non-protein-S. The incorporation of sulphate-S into protein amounted to $0.24 \mathrm{mg} \mathrm{S} / \mathrm{g}$ dry wt. yeast $/ \mathrm{h}$, while the corresponding figures for the incorporation of methionine-S and cysteine-S, estimated from other data, were 0.28 and $0.08 \mathrm{mg} \mathrm{S} / \mathrm{g}$ dry wt. yeast respectively.

From the relatively low concentration of free sulphate in yeast, it appears that sulphate entering the yeast cell is readily converted to organic-S, the rate-limiting step probably being the rate of transport across the cell mernbrane. Methionine on the other hand is much more rapidly taken up 


\section{G. A. MAW}

by the yeast but is incorporated into protein at a comparable rate to sulphate, so that it also accumulates in the non-protein-S fraction. Cysteine is taken up somewhat faster than sulphate and enters protein at a much slower rate, but a further pathway in its utilization is conversion to glutathione, and to what extent this occurs under these conditions has not yet been determined.

\section{FACTORS AFFECTING SULPHATE UPTAKE}

Sulphate uptake was previously studied by Kleinzeller, Kotyk and Kováč ${ }^{39}$ and by Kotyk ${ }^{40}$ in a baker's yeast. The process was shown to require a source of energy, such as glucose, and a supply of nitrogen, such as ammonium ions, and uptake was suppressed by certain metabolic inhibitors. Crocomo and Menard ${ }^{41}$ obtained similar results with Torulopsis utilis.

In experiments with a brewer's yeast the endergonic nature of sulphate uptake has been confirmed. Metabolic inhibitors such as azide and 2,4dinitrophenol which uncouple oxidative phosphorylation, markedly reduce sulphate uptake (Table 7). During an examination of the action of various

Table 7. Effects of some metabolic inhibitors and added sulphate on sulphate uptake by yeast

$\mathrm{Na}_{2}{ }^{35} \mathrm{SO}_{4} 0 \cdot 156 \mathrm{mM}$; yeast $2 \%$ (wet wt. pressed yeast/vol.); temperature $30^{\circ}$; uptake period $1 \mathrm{~h}$; effects of inhibitors expressed as the \% decreases in sulphate uptake compared with controls in the absence of added compounds

\begin{tabular}{|c|c|c|c|c|}
\hline \multirow{2}{*}{ Compound added } & \multicolumn{4}{|c|}{$\begin{array}{c}\% \text { Decrease in sulphate uptake when molar } \\
\text { ratio compound/sulphate is }\end{array}$} \\
\hline & & 2 & 5 & 10 \\
\hline Sodium azide & $57 \cdot 9$ & $70 \cdot 6$ & $85 \cdot 0$ & $98 \cdot 0$ \\
\hline 2,4-Dinitrophenol & $47 \cdot 5$ & 67.4 & 100 & 100 \\
\hline Iodoacetic acid & $47 \cdot 8$ & $78 \cdot 8$ & 100 & - \\
\hline Mercuric chloride & $100 \dagger$ & - & - & - \\
\hline Sodium selenate & $48 \cdot 3$ & $63 \cdot 2$ & $79 \cdot 1$ & $90 \cdot 7$ \\
\hline (Sodium sulphate & $48 \cdot 6$ & $66 \cdot 2$ & $78 \cdot 5$ & $90 \cdot 9)$ \\
\hline
\end{tabular}

$\uparrow 60 \cdot 4 \%$ inhibition at molar ratio $0 \cdot 1$.

inhibitors it was found that selenate strongly depressed sulphate accumulation and that its effect resembled that of added unlabelled sulphate which competes with the uptake of the labelled compound by dilution. Further experiments have shown that selenate is a competitive inhibitor of sulphate transport and that it has an affinity for the absorption sites of the cell comparable with that of sulphate itself. This is in accord with the earlier work of Fels and Cheldelin ${ }^{42}$ who found selenate to be a competitive inhibitor of sulphate in yeast growth. The sulphate uptake mechanism is a fairly specific one. Sulphonic acids, despite their close structural relationship to sulphate, were without effect on uptake. Certain of the sulphur aminoacids, including methionine, ethionine, cysteine and homocysteine were slightly inhibitory, but the reason for this is not clear. 


\section{NUTRIENT REQUIREMENTS FOR SULPHATE}

\section{UPTAKE}

The medium used in the uptake experiments contained glucose, phosphate, ammonium chloride, citrate buffer, salts and vitamins. Experiments were carried out to determine which components of the medium were necessary for optinum uptake. Omission of glucose, ammonium ions or citrate produced significant decreases in uptake whereas omission of the other constituents was without effect. Uptake values amounting to 95-99 per cent of that in the complete medium were obtained with a simplified medium composed of glucose, citric acid-potassium citrate buffer, ammonium chloride and potassium phosphate. As shown in Table 8, omission of glucose

Table 8. Metabolites required for sulphate accumulation by yeast Glucose $0.28 \mathrm{M}$; ammonium chloride and amino-acids $0 \cdot 028 \mathrm{M}$; potassium dihydrogen phosphate $4.04 \mathrm{mM}$; citric acid $5.4 \mathrm{mM}$; potassium citrate $0.015 \mathrm{M}$; acetic acid-sodium acetate buffer, $\mathrm{pH} 5.2,0.02 \mathrm{M} ; \mathrm{Na}_{2}{ }^{35} \mathrm{SO}_{4}$ $0.156 \mathrm{mM}$; yeast $2 \%$ (wet wt. pressed yeast/vol.); temperature $30^{\circ}$; uptake period $1 \mathrm{~h}$

\begin{tabular}{|c|c|}
\hline Composition of medium & $\begin{array}{l}\text { Uptake of } \\
\text { sulphate }\end{array}$ \\
\hline $\begin{array}{l}\text { Complete medium } \\
\text { Water alone } \\
\text { Glucose } \\
\text { Glucose + } \mathrm{NH}_{4} \mathrm{Cl}+\text { citrate + phosphate } \\
\mathrm{NH}_{4} \mathrm{Cl}+\text { citrate + phosphate } \\
\text { Glucose + citrate + phosphate } \\
\text { Glucose + } \mathrm{NH}_{4} \mathrm{Cl}+\text { phosphate } \\
\text { Glucose + } \mathrm{NH}_{4} \mathrm{Cl}+\text { citrate } \\
\text { Glucose + citrate + phosphate + L-aspartic acid } \\
\text { Glucose + citrate + phosphate + L-glutamic acid } \\
\text { Glucose + citrate + phosphate + L-glutamine }\end{array}$ & $\begin{array}{l}100 \\
11 \cdot 2 \\
45 \cdot 7 \\
97 \cdot 1 \\
28 \cdot 2 \\
63 \cdot 1 \\
78 \cdot 3 \\
92 \cdot 6 \\
64 \cdot 5 \\
62 \cdot 3 \\
93 \cdot 2\end{array}$ \\
\hline
\end{tabular}

drastically reduced sulphate uptake. The requirement for ammonium ions and citrate is also apparent. Phosphate was the least essential component of this medium, its omission producing at the most only a slight decrease in uptake. Ammonium ions could be replaced almost completely by equimolar amounts of L-glutamine but not by L-asparagine, L-glutamic acid or Laspartic acid. Furthermore, the function of the citrate was not merely that of a buffer, since its replacement by acetate or phosphate buffers of the same strength and $\mathrm{pH}$ resulted in a distinct decrease in sulphate uptake. The findings summarized in Table 8 place the four components of the medium in the following order of importance for sulphate transport: glucose, ammonium ions, citrate, phosphate.

\section{RÔLE OF NITROGEN IN SULPHATE UPTAKE}

The necessity for a nitrogen supply has been discussed by Kotyk ${ }^{40}$ in terms of the synthesis of a nitrogenous cell component which combines with sulphate as the first step in its metabolism, on the grounds that labelled sulphate-S when taken up by a baker's yeast appeared rapidly in the nucleotide fraction of the cells. Sulphate is known from the work of Wilson and Bandurski ${ }^{43}$ 


\section{G. A. MAW}

to be converted to $3^{\prime}$-phosphoadenosine- $5^{\prime}$-phosphosulphate (PAPS) in yeast, and in this form it can undergo reduction to sulphite and sulphide ${ }^{44,45}$. It is therefore tempting to suggest that PAPS or adenosine-5'-phosphosulphate (APS) may be the form in which sulphate is transported into yeast $^{39}$. This would also explain the competitive effect of selenate on sulphate uptake, since ATP-sulphurylase which catalyses the conversion of sulphate to APS can also use selenate as substrate ${ }^{46}$. More recent work by Spencer 47 has provided evidence that ATP-sulphurylase is directly involved in sulphate uptake and that the ion is transported as APS.

\section{UPTAKE OF SULPHUR AMINO-AGIDS}

Some preliminary studies have been made of the accumulation by a brewer's yeast of methionine, ethionine, $S$-methylcysteine, $S$-ethylcysteine and cysteine. In all cases it was endergonic, being negligible at $0^{\circ}$ and inhibited by azide and 2,4-dinitrophenol. The uptake of each sulphur amino-acid was blocked by only a small number of closely-related compounds, and then only when these were present in relatively high (ten-fold) concentration, as shown in the case of methionine in Table 9. Methionine uptake was depressed to the extent of about 50 per cent or less by ethionine, methionine sulphoxide and sulphone, and homocysteine. Ethionine uptake was reduced by 60 per cent by a ten-fold concentration of methionine, but not by $S$-methylcysteine or $S$-ethylcysteine. $S$-Methylcysteine and $S$-ethylcysteine in ten-fold concentration likewise reduced the uptake of each other

Table 9. Effect of various compounds on the uptake of ${ }_{\mathrm{L}-}\left[{ }^{35} \mathrm{~S}\right]-$ methionine by a brewer's yeast

(Reproduced by courtesy of the Journal of General Microbiology)

L- $\left[{ }^{35} \mathrm{~S}\right]-$ Methionine $0.156 \mathrm{mM}$; yeast $2 \%$ (wet wt. pressed yeast/vol.); temperature $30^{\circ}$; uptake period $20 \mathrm{~min}$; effects of compounds expressed as the \% decrease in metrionine uptake compared with controls in the absence of added compounds

\begin{tabular}{|c|c|c|c|c|}
\hline \multirow[t]{2}{*}{ Compound added } & \multicolumn{4}{|c|}{$\begin{array}{l}\% \text { Decrease in methionine uptake when molar } \\
\text { ratio compound/methionine is }\end{array}$} \\
\hline & 1 & 2 & 5 & 10 \\
\hline $\mathrm{Na}_{2} \mathrm{SO}_{4}$ & $1 \cdot 1$ & $1 \cdot 7$ & $1 \cdot 6$ & $1 \cdot 8$ \\
\hline $\mathrm{L}$-Cysteine $\cdot \mathrm{HCl}$ & $2 \cdot 3$ & $5 \cdot 5$ & $9 \cdot 0$ & $13 \cdot 2$ \\
\hline DL-Homocysteine & $8 \cdot 5$ & $14 \cdot 9$ & $27 \cdot 0$ & $37 \cdot \overline{7}$ \\
\hline S-Methyl-L-cysteine & $6 \cdot 6$ & $9 \cdot 6$ & $13 \cdot 3$ & $16 \cdot 6$ \\
\hline$S$-Ethyl-L-cysteine & - & - & $15 \cdot 2$ & $21 \cdot 4$ \\
\hline DL-Methionine sulphoxide & $11 \cdot 8$ & $20 \cdot 9$ & $36 \cdot 3$ & $46 \cdot 5$ \\
\hline DL-Methionine sulphone & $16 \cdot 1$ & $26 \cdot 4$ & $40 \cdot 4$ & $45 \cdot 9$ \\
\hline L-Ethionine & $12 \cdot 5$ & $20 \cdot 9$ & $32 \cdot 5$ & $46 \cdot 0$ \\
\hline Glutathione (reduced) & $5 \cdot 7$ & $5 \cdot 6$ & $7 \cdot 6$ & $2 \cdot 5$ \\
\hline DL-Norleucine & $\ldots$ & - & $16 \cdot 9$ & $23 \cdot 3$ \\
\hline DL- $\alpha$-Aminobutyric acid & $\ldots$ & - & - & $8 \cdot 9$ \\
\hline$L-\alpha$-Alanine & 一 & - & - & $8 \cdot 9$ \\
\hline Amino-acid mixture A† & $7 \cdot 5$ & & & \\
\hline Amino-acid mixture $\mathrm{B}_{+}^{+}$ & $7 \cdot 9$ & & & \\
\hline Amino-acid mixture $\mathrm{A}+\mathrm{B}$ & $14 \cdot 1$ & & & \\
\hline
\end{tabular}

$\dagger$ Mixture $A$ contained the following amino-acids, each $0.156 \mathrm{mM}: L-\alpha$-alanine, L-arginine-HCl, L-aspartic acid, L-citrulline, $\mathrm{L}$-glutamic acid, glycine, L-proline, L-serine, L-threonine.

$\$$ Mixture $B$ contained the following amino-acids, each $0.156 \mathrm{mM}:$ L-cystine.HCl, L-histidine-HCl, DL-isoleucine, L-leucine, L-lysine $\cdot \mathrm{HCl}$, L-phenylalanine, DL-tryptophan, L-tyrosine, DL-valine. 


\section{SULPHUR UTILIZATION BY YEAST}

by about 60 per cent. Cysteine uptake was partly suppressed ( 32 per cent) by $S$-methylcysteine, but not by homocysteine, and an interesting finding was that it was enhanced by glutathione ( 30 per cent increase at equimolar concentration, 65-80 per cent increase at ten-fold concentration). These rather restricted competitive effects on the uptake of the sulphur aminoacicls suggest that a number of fairly specific transport mechanisms are involved. This contrasts with the findings of other workers ${ }^{48-50}$ on the uptake of such amino-acids as glutamic acid, valine and phenylalanine by yeasts.

T'he competitive effects were shown to operate primarily on the transport of the amino-acids into the cell. This is illustrated in Table 10 by the effects

Table 10. Effects of L-ethionine and DL-methionine sulphone on the partition of L-methionine-sulphur in a brewer's yeast

(Reproduced by courtesy of the Journal of General Microbiology)

L- $\left[{ }^{35} \mathrm{~S}\right]$-Methionine $0.156 \mathrm{mM}$; L-ethionine and DL-methionine sulphone $1.56 \mathrm{mM}$; yeast $2 \%$ (wet wt. pressed yeast/vol.); temperature $30^{\circ}$; uptake period $20 \mathrm{~min}$; figures in parentheses show the \% decreases over the corresponding controls

\begin{tabular}{l|cc}
\hline \multicolumn{1}{c|}{ Compound added } & $\begin{array}{c}\% \text { Uptake of methionine into yeast } \\
\text { TCA-soluble } \\
\text { fraction }\end{array}$ & $\begin{array}{c}\text { TCA-insoluble } \\
\text { fraction }\end{array}$ \\
\hline None & $\mathbf{5 8 . 5}$ & 11.4 \\
L-Ethionine & $26 \cdot 1$ & $10 \cdot 8$ \\
& $(\mathbf{5 5 . 4})$ & $(\mathbf{5 . 3})$ \\
None & $\mathbf{5 1 . 3}$ & $\mathbf{1 0 . 4}$ \\
DL-Methionine sulphone & $\mathbf{2 5 . 4}$ & 9.0 \\
& $(\mathbf{5 0 . 5})$ & $(\mathbf{1 3} \cdot 5)$ \\
\hline
\end{tabular}

of ethionine and methionine sulphone on methionine uptake, which depressed the appearance of methionine in the non-protein-S fraction of the cells. The increase in cysteine uptake produced by glutathione was also primarily an effect on the uptake process (Table 11). This was associated with an increase in the incorporation of cysteine-S into protein which was most probably due to the increased availability of cysteine within the cell.

Table 11. Effect of reduced glutathione on the partition of cysteine-sulphur in a brewer's yeast

(Reproduced by courtesy of the Journal of General Microbiology)

L-[ $\left.{ }^{35} \mathrm{~S}\right]$-Cysteine $\cdot \mathrm{HCl}, 0 \cdot 312 \mathrm{mM}$; reduced glutathione $3.12 \mathrm{mM}$; uptake period $2 \mathrm{~h}$; figures in parentheses show the \% increases over the corresponding controls; other details as in Table 10

\begin{tabular}{l|cc}
\hline \multicolumn{1}{c|}{ Compound added } & $\begin{array}{c}\% \text { Uptake of cysteine into yeast } \\
\text { TCA-soluble } \\
\text { fraction }\end{array}$ & $\begin{array}{c}\text { TCA-insoluble } \\
\text { fraction }\end{array}$ \\
\hline None & $\begin{array}{c}14 \cdot 9 \\
30 \cdot 2\end{array}$ & $9 \cdot 7$ \\
Reduced glutathione & $(104 \cdot 1)$ & $13 \cdot 9$ \\
& & $(43 \cdot 3)$ \\
\hline
\end{tabular}




\section{G. A. MAW}

Acknowledgement is made to the Directors of Arthur Guinness Son $\mathcal{E}$ Co. (Dublin) Ltd., for permission to publish this work.

\section{References}

${ }^{1}$ H. Fink and F. Just. Biochem. Z. 303, 234 (1939).

2 R. J. Block and D. Bolling. Arch. Biochem. 7, 313 (1946).

${ }^{3}$ C. E. Dent. Biochem. J. 41, 314 (1947).

4 P. György. Trans. 3rd Conf. on Biological Antioxidants, Josiah Macy, Jun. Foundation, p. 71 (1948).

5 D. K. McManus, A. S. Schultz, and W. E. Maynard. Anal. Chem. 22, 1187 (1950).

${ }^{6}$ O. Lindan and E. Work. Biochem. J. 48, 337 (1951).

${ }^{7}$ H. Suomalainen and A. J. A. Keränen. Z. Anal. Chem. 148, 81 (1955).

8 D. Ekström and E. Sandegren. Proc. Eur. Brewing Convention 3, 178 (1951).

${ }^{9}$ E. G. Barton-Wright. Proc. Eur. Brewing Convention 1, 19 (1949).

${ }^{10}$ G. A. Maw. J. Inst. Brewing 67, 57 (1961).

${ }^{11}$ R. S. W. Thorne. In Yeasts (Ed. by W. Roman), p. 92, Dr W. Junk, The Hague (1957).

12 P. Bolomey. Ann. Fermentations 5, 221 (1939).

${ }^{13}$ T. Astrup and V. Øhlenschläger. Biochem. J. 42, 211 (1948).

${ }^{14}$ J. L. Stokes, M. Gunness, I. M. Dwyer, and M. C. Caswell. J. Biol. Chem. 160, 35 (1945).

$15 \mathrm{~J}$. L. Stokes and M. Gunness. J. Bacteriol. 52, 195 (1946).

16 M. J. Horn, D. B. Jones, and A. E. Blum. J. Biol. Chem. 166, 313, 321 (1946).

${ }_{17}$ R. Brunner. Mitt. Versuchssta. Gërungsgewerbe Inst. Angew. Mikrobiol. 3, 101 (1949).

${ }^{18}$ G. Tamura, T. Tsunoda, J. Kirimura, and S. Miyazawa. J. Agr. Chem. Soc. Japan 26, 480 (1952).

19 J. S. Chiao and W. H. Peterson. J. Agr. Food Chem. 1, 1005 (1953).

20 W. Baumgarten, A. N. Mather, and L. Stone. Cereal Chem. 23, 135 (1946).

21 G. E. N. Nelson, R. F. Anderson, R. A. Rhodes, M. C. Shekleton, and H. H. Hall. Appl. Microbiol. 8, $179(1960)$.

22 F. Schlenk and R. E. DePalma. J. Biol. Chem. 229, 1037, 1051 (1957).

${ }^{23}$ S. R. Benedict. J. Biol. Chem. 6, 363 (1909).

${ }^{24}$ G. A. Maw. Unpublished observations.

${ }^{25}$ E. Schram, S. Moore, and E. J. Bigwood. Biochem. J. 57, 33 (1954).

${ }^{26}$ S. Moore. J. Biol. Chem. 238, 235 (1963).

27 G. A. Maw. J. Gen. Microbiol. 31, 247 (1963).

${ }^{28}$ R. B. Roberts, P. H. Abelson, D. B. Cowie, E. T. Bolton, and R. J. Britten. Studies of Biosynthesis in Escherichia coli, Carnegie Institute of Washington, Washington (1955).

${ }^{29}$ A. S. Schultz and D. K. McManus. Arch. Biochem. Biophys. 25, 401 (1950).

${ }^{30}$ D. Margolis and R. J. Block. Contrib. Boyce Thompson Inst. 19, 437 (1958).

31 G. A. Maw. J. Inst. Brewing 66, 162 (1960).

32 S. Limbosch-Rolin. Exptl. Cell Res. 29, 61 (1963).

33 L. Massart and J. Horens. Enzymologia 15, 359 (1953).

${ }_{34}$ R. A. Steinberg. J. Agr. Res. Washington 64, 455 (1942).

${ }^{35}$ E. M. C. Turner. Nature 183, 1130 (1959).

${ }_{36}$ P. R. Adaga, K. S. Sastry and P. S. Sarma, J. Gen. Microbiol. 29, 149 (1962).

${ }_{7}$ O. Warburg. Heavy Metal Prosthetic Groups and Enzyme Action, Clarendon Press, Oxford (1949).

38 G. A. Maw. Folia. Microbiol. (Prague) (in the press).

${ }^{39}$ A. Kleinzeller, A. Kotyk, and L. Kováč. Nature 183, 1402 (1959).

40 A. Kotyk. Folia Microbiol. (Prague) 4, 363 (1959).

41 O. J. Grocomo and L. N. Menard. Nature 193, 502 (1962).

42 I. G. Fels and V. H. Cheldelin. Arch. Biochem. Biophys. 22, 402 (1949).

43 L. G. Wilson and R. S. Bandurski. Arch. Biochem. Biophys. 62, 503 (1956).

44 L. G. Wilson and R. S. Bandurski. J. Am. Chem. Soc. 80, 5576 (1958).

45 H. Hilz and M. Kittler. Biochim. Biophys. Acta 30, 650 (1958).

${ }^{46}$ L. G. Wilson and R. S. Bandurski. J. Biol. Chem. 233, 975 (1958).

47 B. Spencer. Private communication.

${ }^{48}$ E. S. Taylor. J. Gen. Microbiol. 3, 211 (1949).

49 H. O. Halvorson and G. N. Cohen. Ann. Inst. Pasteur 95, 73 (1958).

50 M. Massin and A. B. Lindenberg. J. Physiol. (Paris) 50, 407 (1958). 